\title{
ІНСТРУМЕНТАРІЙ ОЦННЮВАННЯ КОРПОРАТИВНОГО УПРАВЛІННЯ В АКЦІОНЕРНИХ ТОВАРИСТВАХ ЗА УМОВ ЕКОНОМІЧНОЇ НЕВИЗНАЧЕНОСТІ
}

\author{
Мігус Ірина Петрівна, \\ доктор економічних наук, професор, \\ професор кафедри управління фінансово-економічною безпекою, \\ ВНЗ «Університет економіки і права «КРОК», \\ ORCID: https://orcid.org/0000-0001-6939-9097
}

Анотація. Досліджено сучасні підходи до корпоративного управління, що дозволило уточнити його визначення. Вивчення зарубіжного та вітчизняного досвіду оцінювання корпоративного управління в акціонерних товариствах дало можливість 3'ясувати, що існуючі методики зазвичай не охоплюють якісні показники. А це в умовах економічної невизначеності негативно впливає на розвиток акціонерного товариства. Запропонована авторська методика передбачає оцінювання корпоративного управління за допомогою як якісних, так i кількісних показників. Якісні показники дозволяють оцінити таке: порядок скликання та проведення Загальних зборів акціонерів; порядок емісії акцій товариства; роботу Спостережної ради товариства; організацію роботи виконавчого органу товариства; розкриття інформації та іiі прозорість; контроль за фінансово-господарською діяльністю товариства. На підставі кількісних показників оцінюються: рентабельність капіталу; рентабельність власного капіталу; період окупності власного капіталу; коєфіцієнт фінансової незалежності; коєфіцієнт фінансової стабільності; прибуток на одну акцію; дивіденд на акцію; дивідендний вихід. Запропонований інструментарій сприятиме більш точному оцінюванню стану корпоративного управління в акціонерних товариствах за умов економічної невизначеності, що дозволить виокремити впливові фактори та удосконалити стратегію розвитку корпорацій.

Ключові слова: акціонерне товариство, корпоративне управління, акція, дивіденди, капітал, інструментарій, економічна невизначеність.

Розвиток підприємницької діяльності в умовах економічної невизначеності, що, крім іншого, пов'язано з інтеграцією України у світовий економічний простір, обумовлює активізацію процесів упровадження вітчизняними компаніями принципів та стандартів корпоративного управління. На користь зростаючої актуальності корпоративного управління для українських підприємств свідчать такі факти. По-перше, у країнах, які розвиваються, впровадження корпоративного управління $є$ однією 3 найважливіших передумов становлення публічного бізнесу, оскільки передбачає визнання загальних 
принципів управління підприємствами, чіткий та прозорий розподіл між основними зацікавленими особами (стейкхолдерами) повноважень і відповідальності за зростання вартості компанії. По-друге, якість корпоративного управління стає одним 3 найвагоміших чинників, що сприяє зменшенню невизначеності середовища функціонування i розвитку компаній унаслідок забезпечення інформаційної прозорості для всіх її стейхолдерів. По-третє, реалізація в компанії трансформаційних за характером проєктів стає поштовхом для якісних та масштабних змін у системі управління. А це практично неможливе без компетентної консалтингової допомоги.

У процесі приватизації і роздержавлення вітчизняних підприємств в Україні відбувається поступове формування інституту корпоративного управління. Зі становленням великого українського бізнесу, активізацією процесів корпоратизації, поширенням компаній холдингового типу суттєво актуалізувалася потреба у формуванні та впровадженні стандартів корпоративного управління.

Незважаючи на зростаючу на сучасному етапі необхідність застосування корпоративних принципів управління бізнесом в акціонерних товариствах, у більшості таких компаній в Україні корпоративне управління де-факто відсутнє або рівень його якості визнається низьким.

Тематична багатогранність і теоретична еклектичність питань ефективності корпоративного управління формують відповідний інформаційний простір дослідження. Засновники теорії корпоративного управління А. Берлі, Г. Мінз у монографії «Сучасна корпорація i приватна власність» [1] визначили два напрями дослідження: особливості управління в корпораціях з різним рівнем концентрації власності та відповідальність менеджменту перед стейкхолдерами. Значний сплеск досліджень системи корпоративного управління був пов'язаний 3 появою і розвитком агентської теорії. Праці видатних науковців М. Дженсена, Г. Демсеця, Б. Клейна, Е. Фамі значною мірою вплинули на формування принципів розподілу відповідальності й повноважень, становлення мотиваційної системи менеджменту корпорації [2].

Роль корпорації, як найскладнішої та найперспективнішої організаційної форми підприємництва, зростає в добу постіндустріального, інформаційного суспільства, оскільки саме вона $\epsilon$ найбільш конкурентоспроможним елементом висококонцентрованої та інтегрованої світової економіки.

Однак проблема пізнання сутності й функціональних і специфічних характеристик, що визначають місце корпорації в економіці країни та іiі відносини з економічними агентами, ще залишається невирішеною.

Низка проблем, пов'язаних зі специфікою корпоративного управління, обумовлена правовими факторами (розпорошення прав власності; ігнорування прав та інтересів індивідуального власника), 
економічними факторами (перевага кваліфікаційних знань і навичок менеджерів, ефект від'ємного синергізму, складність механізмів корпоративного контролю; асиметрія інформації), соціальними факторами (неузгодження економічних інтересів різних груп економічних агентів; детермінованість індивідуальної поведінки власника залежно від статутного внеску) та інституціональними факторами (зміна ролі корпорації як інституту глобальної економіки; зміна місця й ролі власника-акціонера; протиріччя між приватною та колективною основою корпорації) [2].

Вирішення згаданих проблем потребує створення ефективних механізмів взаємодії розрізнених інтересів корпорації як господарюючого суб'єкта і власників, вимагає гармонізації відносин власності та знаходження способів розв' язання протиріч між ними.

Корпорація (від лат. corporatio), за тлумаченням «Сучасного словника іноземних мов», - об'єднання, союз, що утворилися на основі професійних або станових інтересів. Найважливіші характерні ознаки корпорації як нової форми капіталістичних підприємств - концентрація величезних капіталів та надання вирішальної ролі найманим управлінцям визначили А. Берлі й Г. Мінз [1].

У більшості зарубіжних країн корпорації - це організаційні структури, які об'єднали необхідні ресурси для виробництва продукції і надання послуг населенню. Ця форма організації досить популярна в усіх країнах, оскільки:

- обмежує фінансовий ризик акціонерів унаслідок виключення за чинним законодавством їхньої відповідальності перед кредиторами товариства за межами капіталу, що розміщений в акціях;

- робить можливим залучення капіталу за рахунок випуску додаткової кількості акцій та емісії інших цінних паперів;

- продовжує діяльність навіть після зміни складу акціонерів;

- сприяє отриманню інвестицій на вигідних умовах;

- дає змогу власникам корпорацій успішно реалізувати стратегічні плани на засадах колективних інтересів.

Одним із головних чинників, який впливає на успішну діяльність корпорації, є можливість ії доступу до інвестиційного капіталу [1].

Визначення корпорації як акціонерного товариства $\epsilon$ загальноприйнятим та пріоритетним в економічній літературі. За усіх відмінностей у правових базах розвинутих країн основна розмежувальна лінія між корпоративним і некорпоративним секторами полягає у жорсткому розмежуванні власників та управлінців (менеджерів), а також обмеженні відповідальності [3].

В Україні, на жаль, формулювання поняття «корпорація» в чинному законодавстві суттєво відрізняється від загальноприйнятого у світовій практиці. Відповідно до Господарського кодексу України [4] «корпоративне підприємство створюється двома або більше засновниками 
за взаємним рішенням, діє на основі об’єднання майна та/або підприємницької або трудової діяльності засновників (учасників), загального управління справами, на основі корпоративних прав, у тому числі через органи, що ними створюються, участі засновників (учасників) в розподіленні доходів та ризиків підприємства».

Нещодавно прийнятий Закон «Про акціонерні товариства» [5] не розглядає акціонерне товариство як корпорацію, проте вводить таке поняття, як «корпоративне управління».

Поняття «корпоративне управління» широко використовується в західній економічній літературі й досить швидко запроваджується в Україні. Це пояснюється поширеною формою корпоративного господарювання і власності, необхідність управління нею та стрімким розвитком такої власності в Україні. Природа корпоративної власності не $\epsilon$ простою i, відповідно, корпоративне управління як категорія також являє собою складну систему економічних відносин, яка включає багато внутрішніх і зовнішніх елементів [2].

Одним із основоположних аспектів визначення принципів та механізмів підвищення ефективності корпоративного управління $\epsilon$ розуміння його сутнісного наповнення. Огляд підходів до трактування сутності корпоративного управління дозволяє констатувати існування, як мінімум, семи підходів до тлумачення такої дефініції (табл. 1).

Таблиия 1

Основні підходи до визначення поняття «корпоративне управління»

\begin{tabular}{|c|c|}
\hline Підхід & Поняття «корпоративне управління» \\
\hline $\begin{array}{l}\text { Нормативно- } \\
\text { правовий }\end{array}$ & $\begin{array}{l}\text { Система норм законодавства, нормативних положень і практики } \\
\text { господарювання у приватному секторі, що дозволяє компанії здійснювати } \\
\text { господарську діяльність та продовжувати своє функціонування, } \\
\text { нагромаджуючи довгострокову економічну вартість шляхом підвищення } \\
\text { вартості акцій }\end{array}$ \\
\hline $\begin{array}{l}\text { Організаційно- } \\
\text { правовий }\end{array}$ & $\begin{array}{l}\text { Управління організаційно-правовим оформленням бізнесу, оптимізацією } \\
\text { організаційних структур, побудовою внутрішньо- та міжфірмових } \\
\text { взаємозв’ язків компанії у відповідності до прийнятих цілей }\end{array}$ \\
\hline Реляційний & $\begin{array}{l}\text { Система взаємовідносин між інвесторами-власниками, менеджерами та } \\
\text { зацікавленими особами задля забезпечення ефективної діяльності товариства, } \\
\text { рівноваги балансу інтересів учасників корпоративних відносин }\end{array}$ \\
\hline Управлінський & $\begin{array}{l}\text { Управління культурою корпорації, тобто комплексом загальних традицій та } \\
\text { установок, принципів поведінки компанії стосовно основних їі підсистем } \\
\text { елементів, а також стосовно суспільства }\end{array}$ \\
\hline $\begin{array}{l}\text { Організаційно- } \\
\text { управлінський }\end{array}$ & $\begin{array}{l}\text { Система органів, посад, механізмів та функцій, що реалізують регулюючий } \\
\text { вплив на діяльність компанії }\end{array}$ \\
\hline Фінансовий & $\begin{array}{l}\text { Система органів та механізмів управлінського впливу, яка забезпечує } \\
\text { безперервний оптимальний рух фінансових потоків компанії }\end{array}$ \\
\hline $\begin{array}{l}\text { Фінансово- } \\
\text { майновий }\end{array}$ & $\begin{array}{l}\text { Обраний спосіб самоуправління, що забезпечує справедливий і рівноправний } \\
\text { розподіл результатів діяльності між усіма акціонерами, а також «фінансово } \\
\text { зацікавленими особами, насамперед кредиторами та інвесторами» }\end{array}$ \\
\hline
\end{tabular}


Така різноманітність підходів до розуміння сутності корпоративного управління зумовлює багатоформатність оцінювання його ефективності. Зазначимо, що ефективність корпоративного управління доцільно розглядати у трьох площинах:

1) юридично-правове забезпечення прав власників компанії, їх інтересів і повноважень щодо формування й управління власністю;

2) економіко-правова та ментальна складова формування механізму корпоративного управління;

3) забезпечення дієвості розробленої системи корпоративного управління та підвищення пї ефективності.

Отже, корпоративне управління - це сучасний вид управлінської діяльності акціонерного товариства, який характеризується наявністю корпоративної стратегії, корпоративного стилю роботи менеджерів усіх рівнів, корпоративної культури, фінансової та інформаційної відкритості, системи захисту прав акціонерів і власників інших цінних паперів підприємства-емітента.

До основних завдань корпоративного управління можна віднести:

- створення і забезпечення діяльності ефективного механізму аналізу, поточного й стратегічного управління, прийняття управлінських рішень та контроль за діяльністю товариства;

- забезпечення однакового і справедливого ставлення до всіх акціонерів;

- балансування інтересів акціонерів, менеджерів, працівників, клієнтів, партнерів і постачальників акціонерного товариства, тобто зацікавлених осіб, держави та суспільства [10].

Враховувати інтереси різних груп акціонерів дозволяє використання, запровадження і законодавче закріплення принципів корпоративного управління. Принципи корпоративного управління - це документ, що визначає правила, за якими вибудовуються стосунки на фінансових ринках у всьому світі й дотримання яких є однією 3 необхідних умов залучення інвестицій. Організація з питань економічного співробітництва та розвитку (ОЕСР) розробила перелік загальних принципів корпоративного управління, що можуть бути використані в законодавстві країнами 3 перехідною економікою. Ці принципи, що не $є$ обов'язковими для застосування навіть для країн-членів ОЕСР, являють собою спробу міжнародної спільноти створити загальноприйняті основи корпоративного управління. ОЕСР детально визначає п'ять принципів сучасного корпоративного управління (додаток А).

Система корпоративного управління - це організаційна модель, за допомогою якої компанія представляє і захищає інтереси своїх інвесторів. Тип застосування моделі залежить від структури компанії, що існує в межах ринкової економіки, і відображає сам факт поділу функцій управління та володіння корпорацією [11]. 
У розвинутих країнах світу існують різні моделі корпоративного управління. Модель корпоративного управління - це відображення найбільш суттєвих характеристик, властивостей та закономірностей функціонування корпоративного управління як об'єкта соціальноекономічної реальності, що створюється дослідником з метою отримання нових знань про систему корпоративного управління відповідно до мети дослідження [12]. Спеціалісти виділяють три моделі корпоративного управління: англо-американську, японську та німецьку.

Англо-американська модель (застосовується в корпораціях Великої Британії, США, Австралії, Нової Зеландії, Канади і деяких інших країн), характеризується наявністю індивідуальних та інституційних інвесторів і кількістю незалежних (яка постійно зростає), тобто не пов'язаних 3 корпорацією акціонерів (їх називають «зовнішніми» або «аутсайдерами»), а також чітко розробленою законодавчою базою, яка визначає права й обов'язки трьох ключових учасників - ради директорів, менеджерів і акціонерів [11].

Японська модель грунтується на тісному зв'язку з ключовим банком та фінансово-промисловою мережею (кейрецу). Банк надає своїм корпоративним клієнтам кредити і послуги з випуску цінних паперів, ведення розрахункових рахунків, консалтингові послуги. Цей банк найчастіше і $є$ основним внутрішнім акціонером компанії. Незалежні акціонери фактично не спроможні впливати на політику фірми, тому їхня кількість доволі незначна [11].

Німецька модель заснована на банківській системі (банки виступають кредиторами, голосуючими агентами, депозитаріями), акціонерах та працівниках [12]. Німецька модель має три унікальні особливості, що відрізняють їі від інших моделей: двопалатне правління, що складається з виконавчої і наглядової (спостережної) рад; узаконені обмеження прав акціонерів щодо голосування, тобто статут підприємства обмежує кількість голосів, які акціонер має на зборах, що може не збігатися з кількістю акцій, власником яких він $є$ [12].

Поліпшення корпоративного управління $є$ пріоритетним питанням для України, яка стала на шлях ринкової економіки. Недостатня увага до проблем корпоративного управління може призвести до ослаблення конкурентних позицій корпорацій. Особливого розгляду потребують питання формування корпоративної власності й механізму управління економічною безпекою як важливі умови успішної та ефективної діяльності корпоративних організацій.

Сьогодні система корпоративного управління в Україні проходить етап розвитку і становлення, що характеризується наявністю загальних рис як з англо-американською (основну роль відіграють інституційні інвестори й акціонери), так і з німецькою (система управління компанією складається з виконавчої й наглядової (спостережної) рад) та японською 
(деякі ринки мають ознаки існування ключового банку й фінансовопромислової мережі, акціонери-інсайдери заінтересовані в довгостроковому контролі над товариством більше, ніж в отриманні швидкого прибутку) моделями.

Серед домінуючих чинників, що сприяють формуванню інституту корпоративного управління в Україні, слід виділити інституційні та інтеграційні тенденції ринкових перетворень, активне залучення зовнішнього інвестування, а також боротьбу з ризиками недружнього поглинання.

Сьогодні корпоративний сектор вітчизняної економіки включає великі торговельні, логістичні, промислові компанії, промисловофінансові групи, холдингові та транснаціональні компанії, які мають визначальну роль у забезпеченні економічного зростання країни. Саме вони стають активними гравцями фінансових ринків, ведуть пошук зовнішніх джерел фінансування через механізм виходу на IPO.

Суттєвим поштовхом до впровадження в українських компаніях стандартів управління корпоративним бізнесом може стати глобальна фінансова криза. Як правило, складні економічні умови можуть не тільки перешкоджати успішному розвитку компаній, але й створити передумови для пошуку шляхів удосконалення або кардинальної зміни принципів державного управління та практики управління реальним бізнесом. Однією 3 причин світового економічного спаду аналітики визнають необгрунтовані фінансові рішення інвесторів, які призвели до значних втрат національного і приватного капіталу. Більшість експертів вважають, що корпоративне управління має стати дієвим механізмом забезпечення реалізації інтересів власників та інвесторів, упровадження нової управлінської логіки, яка базується на підходах пріоритетності добробуту власників компанії.

Корпоративне управління є важливим елементом ефективної ринкової економіки. Акціонери й інші зацікавлені особи повинні мати доступ до відповідної інформації та можливість здійснювати контроль і вплив стосовно керівництва 3 метою забезпечення використання активів компанії в інтересах усіх цих осіб. Контроль здійснюється за допомогою як внутрішніх процедур управління, так і зовнішніх правових регулюючих механізмів. Можливість здійснення такого контролю важлива як в економічно розвинених країнах, так і в країнах з економікою, що розвивається.

Для інвесторів і кредиторів повинні бути зрозумілі та прийнятні ті форми, в яких акціонери реалізують свою здатність здійснювати контроль за діяльністю керівництва і брати участь у найважливіших рішеннях.

Сумлінна практика корпоративного управління служить заставою того, що наступні компанії враховують інтереси широкого кола зацікавлених осіб і що їхнє керівництво підзвітне ії акціонерам. Це, у 
свою чергу, допомагає підтримувати довіру з боку інвесторів як іноземних, так і вітчизняних та залучати довгострокові кредити [13].

Використовуючи відповідну методологію оцінки корпоративного управління, слід аналізувати систему взаємодії між керівництвом компанії, іiі наглядовою радою, акціонерами й іншими зацікавленими особами, а також проводити всебічну оцінку стандартів управління за чотирма самостійними компонентами, а саме [14]:

- структура власності та вплив з боку власників;

- відносини із зацікавленими особами;

- фінансова прозорість і розкриття інформації;

- структура і методи роботи органів управління.

Складання рейтингу корпоративного управління регламентується Методичними рекомендаціями щодо створення та діяльності незалежних інформаційних і рейтингових агентств, що спеціалізуються на наданні інформаційних послуг на фондовому ринку України, які, в свою чергу, розроблені на основі Концепції створення системи рейтингової оцінки регіонів, галузей національної економіки, суб'єктів господарювання [15].

Рейтинг корпоративного управління та здійснюваний 3 цією метою аналіз дозволяють такій компанії позиціонуватися стосовно інших емітентів цінних паперів у конкурентному ринковому середовищі. Рейтинг корпоративного управління передбачає проведення аналізу ефективності взаємодії між керівництвом, наглядовою радою й акціонерами компанії та іншими особами, що мають у ній фінансовий інтерес. Головним об'єктом аналізу є внутрішня структура і методи корпоративного управління [16-23]. Основна увага приділяється тому, наскільки виконуються мінімальні вимоги місцевого законодавства та регулюючих принципів і може включати у себе аналіз корпоративного управління у країні (аналіз правової, регулюючої й інформаційної інфраструктури).

Рейтинг корпоративного управління компанії представляє собою поточний висновок щодо рівня відповідності практики корпоративного управління цієї компанії кодексам і принципам та кращій практиці у цій сфері [13].

Окрім цього, балами за шкалою від вищого до нижчого може оцінюватися кожний з чотирьох окремих компонентів. Ідеться про такі компоненти і субкомпоненти:

1. Структура корпоративного капіталу:

- прозорість структури;

- концентрація капіталу і вплив з боку власників.

2. Відносини із зацікавленими особами:

- регулярність проведення зборів акціонерів, можливість в них участі в них й одержання інформації про їх проведення;

- процедури голосування і ведення зборів акціонерів; 
- права власності (реєстрація і передача, рівність прав власності).

3. Фінансова прозорість і розкриття інформації:

- стандарти розкриття інформації;

- своєчасність і доступність інформації, що розкривається;

- незалежність аудитора.

4. Структура і методи роботи органів управління компанії:

- структура і склад наглядової ради;

- роль і ефективність ради директорів;

- незалежність зовнішніх директорів;

- політика у сфері винагород, оцінки результатів роботи осіб органів управління компанії.

В умовах економічної невизначеності існуючі методики виглядають недосконалими, оскільки не враховують одночасно якісні та кількісні показники, що знижує загальний ефект від такого оцінювання. Саме тому Методика складання рейтингу корпоративного управління, яка пропонується [13], базується не лише на оцінці якісних показників управління акціонерним товариством, а й на кількісних показниках його діяльності (рис. 1).

\section{ЯКІСНІ ПОКАЗНИКИ}

- порядок скликання та проведення Загальних зборів акціонерів;

- порядок емісії акцій товариства;

- робота Спостережної ради товариства;

- організація роботи виконавчого органу товариства;

- розкриття інформації та ії прозорість;

- контроль за фінансово-господарською діяльністю товариства.

\section{КІЛЬКІСНІ ПОКАЗНИКИ}

- рентабельність капіталу;

- рентабельність власного капіталу;

- період окупності власного капіталу;

- коефіцієнт фінансової незалежності;

- коефіцієнт фінансової стабільності;

- прибуток на одну акцію;

- дивіденд на акцію

- дивідендний вихід.

\section{Рис. 1. Якісні та кількісні показники оцінки стану корпоративного управління акціонерних товариств}

Джерело: розроблено автором самостійно.

Рейтинг складається лише на основі публічних даних, розкритих акціонерним товариством на сайтах інформаційних агентств, уповноважених Державною комісією з цінних паперів та фондового 
ринку і на сайті самого товариства. На підставі розробленої автором анкети (додаток Б), проводиться систематизація інформації для визначення та оцінки якісних показників. Порядок скликання й проведення загальних зборів акціонерів оцінюють за такими ознаками (табл. 2).

Таблиця 2

\section{Порядок скликання та проведення загальних зборів акціонерів}

\begin{tabular}{|l|c|}
\hline \multicolumn{1}{|c|}{ Показник } & Бали \\
\hline $\begin{array}{l}\text { Загальні збори акціонерів проводятьяя щороку, акціонери мають доступ до } \\
\text { документів, пов'язаних 3 порядком денним, мають право вносити пропозиції } \\
\text { щодо порядку денного, беруть участь в обговоренні та голосуванні, а також } \\
\text { одержують повну і достовірну інформацію про фінансово-господарський } \\
\text { стан Товариства та результати його діяльності }\end{array}$ & 5 балів \\
\hline $\begin{array}{l}\text { Загальні збори акціонерів проводяться щороку, акціонери мають доступ до } \\
\text { документів, пов'язаних з порядком денним та мають право вносити пропозиції } \\
\text { щодо порядку денного, беруть участь в обговоренні й голосуванні з питань } \\
\text { порядку денного, використовуючи бюлетені затвердженої форми }\end{array}$ & 4 бали \\
\hline $\begin{array}{l}\text { Загальні збори акціонерів проводятья щороку, акціонери мають право } \\
\text { доступу до документів, пов'язаних з порядком денним та вносити пропозиції } \\
\text { щодо доповнення порядку денного окремими питаннями не пізніше 30 днів } \\
\text { до скликання загальних зборів }\end{array}$ & 3 бали \\
\hline $\begin{array}{l}\text { Загальні збори акціонерів проводятья щороку, Товариство забезпечує } \\
\text { акціонерам можливість у будь-який час з моменту повідомлення про скликання } \\
\text { загальних зборів до дня їх проведення ознайомитися з документами, пов’язаними } \\
\text { з порядком денним }\end{array}$ & 2 бали \\
\hline $\begin{array}{l}\text { Загальні збори акціонерів проводяться щороку не пізніше 4 місяців після } \\
\text { закінчення фінансового року, акціонери повідомляютьяя про це не пізніше } \\
\text { як за 45 днів до їх проведення }\end{array}$ & 1 бал \\
\hline
\end{tabular}

Джерело: розроблено автором самостійно.

Порядок емісії акцій товариства оцінюють за такими ознаками (табл. 3).

Табличя 3

Порядок емісії акцій товариства

\begin{tabular}{|l|c|}
\hline \multicolumn{1}{|c|}{ Показник } & Бали \\
\hline $\begin{array}{l}\text { Товариство здійснювало емісію іменних акцій та акцій на пред’яника, звичайні } \\
\text { й привілейовані в бездокументарній формі, реєстр ведеться у депозитарії }\end{array}$ & 5 балів \\
\hline $\begin{array}{l}\text { Товариство здійснювало додаткові емісії звичайних іменних акцій у } \\
\text { бездокументарній формі, реєстр ведеться у депозитарії }\end{array}$ & 4 бали \\
\hline $\begin{array}{l}\text { Товариство здійснювало додаткові емісії звичайних іменних акцій у у } \\
\text { документарній формі, реєстр ведеться незалежним реєстратором }\end{array}$ & 3 бали \\
\hline $\begin{array}{l}\text { Товариство здійснювало емісію звичайних іменних акцій у документарній } \\
\text { формі лише при створенні, реєстр ведеться незалежним реєстратором }\end{array}$ & 2 бали \\
\hline $\begin{array}{l}\text { Товариство здійснювало емісію звичайних іменних акцій у документарній } \\
\text { формі лише при створенні, реєстр ведеться на підприємстві }\end{array}$ & 1 бал \\
\hline
\end{tabular}

Джерело: розроблено автором самостійно.

Робота спостережної ради товариства оцінюється за такими ознаками (табл. 4). 


\section{Робота спостережної ради товариства}

\begin{tabular}{|c|c|}
\hline Показник & Бали \\
\hline $\begin{array}{l}\text { Спостережна рада здійснює контроль за діяльністю виконавчого органу, } \\
\text { захист прав усіх акціонерів, звітує перед Загальними зборами акціонерів, має } \\
\text { у своєму складі незалежних членів, визначає основні цілі діяльності } \\
\text { Товариства, ухвалює стратегію для їх досягнення, щорічно проводить оцінку } \\
\text { своєї діяльності, в тому числі й за допомогою рейтингу. В своїй } \\
\text { організаційній структурі має посаду корпоративного секретаря }\end{array}$ & 5 балів \\
\hline $\begin{array}{l}\text { Спостережна рада здійснює контроль за діяльністю виконавчого органу, } \\
\text { захист прав усіх акціонерів, звітує перед Загальними зборами акціонерів, має } \\
\text { у своєму складі незалежних членів, визначає основні цілі діяльності } \\
\text { Товариства, ухвалює стратегію для їх досягнення }\end{array}$ & 4 бали \\
\hline $\begin{array}{l}\text { Спостережна рада здійснює контроль за діяльністю виконавчого органу, } \\
\text { захист прав усіх акціонерів, звітує перед Загальними зборами акціонерів, ії } \\
\text { члени володіють необхідними знаннями та досвідом. До іï складу входять } \\
\text { незалежні члени }\end{array}$ & 3 бали \\
\hline $\begin{array}{l}\text { Спостережна рада здійснює контроль за діяльністю виконавчого органу, } \\
\text { захист прав усіх акціонерів, звітує перед Загальними зборами акціонерів, ії } \\
\text { члени володіють знаннями, кваліфікацією та досвідом, необхідними для } \\
\text { виконання своїх обов'язків }\end{array}$ & 2 бали \\
\hline $\begin{array}{l}\text { Спостережна рада здійснює контроль за діяльністю виконавчого органу на } \\
\text { громадських засадах, її члени не мають достатньої кваліфікації та досвіду } \\
\text { роботи у цій сфері }\end{array}$ & 1 бал \\
\hline
\end{tabular}

Джерело: розроблено автором самостійно.

\section{Організація роботи виконавчого органу товариства оцінюється} за такими ознаками (табл. 5).

Таблиия 5

Організація роботи виконавчого органу товариства

\begin{tabular}{|l|c|}
\hline \multicolumn{1}{|c|}{ Показник } & Бали \\
\hline $\begin{array}{l}\text { Виконавчий орган здійснює поточне та перспективне управління Товариством, } \\
\text { подає Спостережній раді звіт про виконання оперативних і перспективних } \\
\text { планів та про фінансово-господарський стан діяльності Товариства }\end{array}$ & 5 балів \\
\hline $\begin{array}{l}\text { Виконавчий орган здійснює поточне та перспективне управління Товариством, } \\
\text { не рідше 1 разу на три місяці подають Спостережній раді звіт про виконання } \\
\text { оперативних планів Товариства }\end{array}$ & 4 бали \\
\hline $\begin{array}{l}\text { Виконавчий орган здійснює поточне та перспективне управління Товариством } \\
\text { відповідно до законодавства }\end{array}$ & 3 бали \\
\hline $\begin{array}{l}\text { Виконавчий орган розробляє та узгоджує із Спостережною радою проєкти } \\
\text { річного бюджету та стратегії Товариства }\end{array}$ & 2 бали \\
\hline Виконавчий орган здійснює керівництво поточною діяльністю Товариства & 1 бал \\
\hline
\end{tabular}

Джерело: розроблено автором самостійно.

Розкриття інформації та іiі прозорість оцінюють за такими ознаками (табл. 6).

Контроль за фінансово-господарською діяльністю товариства оцінюють за такими ознаками (табл. 7). 
Таблиия 6

Розкриття інформації та її прозорість

\begin{tabular}{|l|c|}
\hline \multicolumn{1}{|c|}{ Показник } & Бали \\
\hline $\begin{array}{l}\text { Товариство регулярно розкриває не лише річну, а й квартальну звітність у } \\
\text { офіційних виданнях та на Інтернет-сайті, а також розповсюджує річний звіт } \\
\text { разом з аудиторським висновком серед акціонерів, клієнтів, партнерів й } \\
\text { інвесторів. Про всі зміни у фінансово-господарській діяльності, які можуть } \\
\text { вплинути на вартість цінних паперів або доходу по них, Товариство } \\
\text { повідомляє не пізніше } 2 \text { днів } 3 \text { дати виникнення. Товариство регулярно } \\
\text { звертається до рейтингових агентств }\end{array}$ & \\
\hline $\begin{array}{l}\text { Товариство регулярно розкриває не лише річну, а й квартальну звітність у } \\
\text { офіційних виданнях та на Інтернет-сайті, а також розповсюджує річний звіт } \\
\text { разом з аудиторським висновком серед акціонерів, клієнтів, партнерів й інвесторів }\end{array}$ & 4 бали \\
\hline $\begin{array}{l}\text { Товариство регулярно розкриває не лише річну, а й квартальну звітність у } \\
\text { офіційних виданнях та на Інтернет-сайті }\end{array}$ & 3 бали \\
\hline $\begin{array}{l}\text { Товариство регулярно здає річний звіт, форма якого передбачена ДКЦПФР } \\
\text { та публікує його в одному з офіційних видань, а також розміщує електронний } \\
\text { варіант звіту на Інтернет-сайті }\end{array}$ & 2 бали \\
\hline $\begin{array}{l}\text { Товариство регулярно здає річний звіт, форма якого передбачена ДКЦПФР } \\
\text { та публікує його в одному з офіційних видань }\end{array}$ & 1 бал \\
\hline
\end{tabular}

Джерело: розроблено автором самостійно.

Таблиця 7

Контроль за фінансово-господарською діяльністю товариства

\begin{tabular}{|l|c|}
\hline \multicolumn{1}{|c|}{ Показник } & Бали \\
\hline $\begin{array}{l}\text { 3 метою захисту прав та інтересів акціонерів Товариство звертається до } \\
\text { незалежної аудиторської фірми, яка не змінюється. Досить ефективно } \\
\text { працює ревізійна комісія Товариства та його Спостережна рада. Товариством } \\
\text { створено відділ Внутрішнього контролю (аудиту) }\end{array}$ & балів \\
\hline $\begin{array}{l}3 \text { метою захисту прав та інтересів акціонерів Товариство звертається до } \\
\text { незалежної аудиторської фірми, яка не змінюєтья. Досить ефективно } \\
\text { працюють ревізійна комісія Товариства і його Спостережна рада }\end{array}$ & 4 бали \\
\hline $\begin{array}{l}\text { н метою захисту прав та інтересів акціонерів Товариство звертається до } \\
\text { незалежної аудиторської фірми, яка не змінюється останні 3-5 років. Досить } \\
\text { ефективно працює ревізійна комісія Товариства }\end{array}$ & 3 бали \\
\hline $\begin{array}{l}3 \text { метою захисту прав та інтересів акціонерів Товариство звертається до } \\
\text { незалежних аудиторських фірм, які не змінюються останні 3 роки }\end{array}$ & 2 бали \\
\hline $\begin{array}{l}3 \text { метою захисту прав та інтересів акціонерів Товариство звертається до } \\
\text { незалежних аудиторських фірм, які постійно змінюються }\end{array}$ & 1 бал \\
\hline
\end{tabular}

Джерело: розроблено автором самостійно.

Рентабельність капіталу розраховується за такою формулою $\left(X_{7}\right)$ [24]:

$$
X_{7}=\frac{\text { ЧП }}{A}=\frac{\text { ф. } 2 \text { ряд } .220}{\text { ф.1 ряд } .280}
$$

де ЧП - чистий прибуток товариства, $A$ - загальна сума активів.

Рентабельність капіталу показує, скільки гривень чистого прибутку припадає на 1 грн інвестованих в активи коштів. Збільшення 
цього показника характеризує позитивні зміни у діяльності товариства. Рентабельність капіталу доцільно оцінити так (табл. 8).

Таблиия 8

\section{Рентабельність капіталу}

\begin{tabular}{|l|c|}
\hline \multicolumn{1}{|c|}{ Показник } & Бали \\
\hline перевищус 0,1 & 5 балів \\
\hline у межах від 0,05 до 0,1 & 4 бали \\
\hline у межах від 0,0 до 0,05 & 3 бали \\
\hline у межах від -0,1 до 0,0 & 2 бали \\
\hline менше -0,1 & 1 бал \\
\hline
\end{tabular}

Рентабельність власного капіталу розраховується за такою формулою $\left(X_{8}\right)[25]$ :

$$
X_{8}=\frac{\text { ЧП }}{B K}=\frac{\phi .2 \text { ряд } .220}{\text { ф.1 ряд } .380}
$$

де ЧП - чистий прибуток, $B K$ - загальна сума власного капіталу товариства.

Рентабельність власного капіталу показує, скільки гривень чистого прибутку припадає на 1 грн інвестованих у власний капітал товариства коштів.

Рентабельність власного капіталу доцільно оцінити так (табл. 9).

Рентабельність власного капіталу
\begin{tabular}{|l|c|}
\hline \multicolumn{1}{|c|}{ Показник } & Бали \\
\hline перевищує 0,1 & 5 балів \\
\hline у межах від 0,05 до 0,1 & 4 бали \\
\hline у межах від 0,0 до 0,05 & 3 бали \\
\hline у межах від -0,1 до 0,0 & 2 бали \\
\hline менше - 0,1 & 1 бал \\
\hline
\end{tabular}

Таблиия 9

Період окупності власного капіталу розраховується за такою формулою $\left(X_{9}\right)[27]$ :

$$
X_{9}=\frac{B K}{\text { ЧП }}=\frac{\text { ф.1 ряд } .380}{\text { ф. } 2 \text { ряд } .220}
$$

де ЧП - чистий прибуток підприємства, $B K$ - загальна сума власного капіталу.

Період окупності власного капіталу показує, скільки, за який період власний капітал буде компенсований чистим прибутком товариства. Чим меншим буде цей показник, тим краще.

Період окупності власного капіталу доцільно оцінити так (табл. 10). 


\section{Період окупності власного капіталу}

Таблиияя 10

\begin{tabular}{|l|c|}
\hline \multicolumn{1}{|c|}{ Показник } & Бали \\
\hline $\begin{array}{l}\text { менше за операційний цикл } \\
\text { (менше 1 року) }\end{array}$ & 5 балів \\
\hline у межах від 1,0 до 1,5 року & 4 бали \\
\hline у межах від 1,5 до 2,0 років & 3 бали \\
\hline у межах від 2,0 до 2,5 років & 2 бали \\
\hline Перевищує 3 роки & 1 бал \\
\hline
\end{tabular}

Коєфіцієнт фінансової стійкості (незалежності) розраховується за такою формулою $\left(X_{10}\right)[13]$ :

$$
X_{10}=\frac{B K}{M}=\frac{\text { ф.1 ряд } .380}{\text { ф.1 ряд } .640}
$$

де $B K$ - власний капітал, $M$ - загальна сума майна товариства.

Характеризує можливість підприємства виконати свої зовнішні зобов'язання за рахунок власних джерел та показує незалежність підприємства від позикових джерел фінансування. Критичне значення - 0,5. При зменшенні значення коєфіцієнта підприємство втрачає свою незалежність.

Коєфіцієнт фінансової стійкості (незалежності) доцільно оцінити так (табл. 11).

Таблиияя 11

\section{Оцінка косфіцієнта фінансової стійкості (незалежності)}

\begin{tabular}{|l|c|}
\hline \multicolumn{1}{|c|}{ Показник } & Бали \\
\hline перевищує 1,0 & 5 балів \\
\hline у межах від 0,75 до 1,0 & 4 бали \\
\hline у межах від 0,5 до 0,75 & 3 бали \\
\hline у межах від 0,2 до 0,5 & 2 бали \\
\hline менше 0,2 & 1 бал \\
\hline
\end{tabular}

Коєфіцієнт фінансової стабільності (коєфіцієнт фінансування) розраховується за такою формулою $\left(X_{11}\right)$ [27]:

$$
X_{11}=\frac{B K}{\text { ДЗ } П \text { П3 }}=\frac{\text { ф.1 ряд. } 380}{\text { ф.1 ряд. } 480+\text { ф. } 1 \text { ряд. } 620}
$$

де $B K$ - власний капітал підприємства, ДЗ - довгострокові зобов'язання підприємства, ПЗ - поточні зобов'язання підприємства.

Коєфіцієнт фінансової стабільності показує забезпеченість заборгованості власними коштами. Критичне значення - 0,5. При зменшенні коєфіцієнта підприємство втрачає свою фінансову стабільність. 
Коєфіцієнт фінансової стабільності доцільно оцінити так (табл. 12).

Косфіціснт фінансової стабільності

Таблиця 12

\begin{tabular}{|l|c|}
\hline \multicolumn{1}{|c|}{ Показник } & Бали \\
\hline перевищує 1,0 & 5 балів \\
\hline у межах від 0,75 до 1,0 року & 4 бали \\
\hline у межах від 0,5 до 0,75 року & 3 бали \\
\hline у межах від 0,25 до 0,5 року & 2 бали \\
\hline менше 0,25 & 1 бал \\
\hline
\end{tabular}

Прибуток на одну акцію розраховується за такою формулою $\left(X_{12}\right)[13]:$

$$
X_{7}=\frac{\text { ЧП }}{3 в А \kappa}=\frac{\phi .2 \text { ряд } .220}{\text { ф. } 2 \text { ряд. } 300}=\text { ф. } 2 \text { ряд. } 320
$$

де ЧП - чистий прибуток підприємства, ЗвАк - кількість випущених звичайних (простих) акцій товариства.

Прибуток на одну акцію показує, скільки гривень чистого прибутку припадає на одну звичайну акцію товариства. Зростання цього показника свідчить про покращення корпоративного управління діяльністю товариства.

Прибуток на одну акцію доцільно оцінити так (табл. 13).

Таблиия 13

Прибуток на одну акцію

\begin{tabular}{|l|c|}
\hline \multicolumn{1}{|c|}{ Показник } & Бали \\
\hline вище номінальної вартості акції більше, ніж у 2 рази & 5 балів \\
\hline вище номінальної вартості акції менше, ніж у 2 рази & 4 бали \\
\hline дорівнює номінальній вартості акцій & 3 бали \\
\hline нижче номінальної вартості акції менше, ніж у 2 рази & 2 бали \\
\hline нижче номінальної вартості акції більше, ніж у 2 рази & 1 бал \\
\hline
\end{tabular}

Дивіденд на акцію розраховується за такою формулою $\left(X_{13}\right)[13]$ :

$$
X_{13}=\frac{\text { Дза- Дпа }}{\text { ЗвАк }}=\text { ф. } 2 \text { ряд. } 340
$$

де Дза - сума дивідендів за звичайними акціями, Дп $а$ - сума дивідендів за привілейованими акціями, ЗвАк - кількість випущених звичайних акцій товариства.

Дивіденд на акцію показує, скільки гривень чистого прибутку після сплати дивідендів за привілейованими акціями припадає на одну звичайну акцію товариства.

Дивіденд на акцію доцільно оцінити так (табл. 14). 


Дивіденд на акцію
\begin{tabular}{|l|c|}
\hline \multicolumn{1}{|c|}{ Показник } & Бали \\
\hline вище номінальної вартості акції більше, ніж у 2 рази & 5 балів \\
\hline вище номінальної вартості акції менше, ніж у 2 рази & 4 бали \\
\hline дорівнює номінальній вартості акцій & 3 бали \\
\hline нижче номінальної вартості акції менше, ніж у 2 рази & 2 бали \\
\hline нижче номінальної вартості акції більше, ніж у 2 рази & 1 бал \\
\hline
\end{tabular}

Дивідендний вихід розраховується за такою формулою $\left(X_{14}\right)$ [13]:

$$
X_{14}=\frac{X_{13}}{X_{12}}=\frac{\text { ф. } 2 \text { ряд. } 340}{\text { ф. } 2 \text { ряд. } 320}
$$

де $X_{13}$ - дивіденд на акцію, $X_{12}$ - прибуток на акцію товариства.

Дивідендний вихід показує частку дивідендів за звичайними акціями до сплати у чистому прибутку товариства. Залежить від дивідендної політики товариства.

Дивідендний вихід доцільно оцінити так (табл. 15).

Табличя 15

Дивідендний вихід
\begin{tabular}{|l|c|}
\hline \multicolumn{1}{|c|}{ Показник } & Бали \\
\hline перевищує 1,0 & 5 балів \\
\hline у межах від 0,75 до 1,0 & 4 бали \\
\hline у межах від 0,5 до 0,75 & 3 бали \\
\hline у межах від 0,2 до 0,5 & 2 бали \\
\hline менше 0,2 & 1 бал \\
\hline
\end{tabular}

На основі проведених експертних опитувань (додаток В) попередньо оціненим показникам присвоюються відповідні вагові коєфіцієнти (табл. 16).

Зазначені вагові коєфіцієнти були визначені на основі опитування спеціалістів, що працюють наразі на підприємствах різних форм власності, а також у банківських установах, інвестиційних компаніях, державних структурах тощо. Сумарний бал оцінки рівня корпоративного управління акціонерного товариства визначається множенням кількості отриманих балів за кожним фактором на ваговий коєфіцієнт з подальшим сумуванням отриманих результатів:

$$
R_{\text {crop }}=F\left(X_{i}\right)=\sum_{i=1}^{n}\left[B_{i} \times K_{i}\right]
$$

де $R_{\text {crop }}$ - сумарний бал оцінки рівня корпоративного управління Товариства; $B_{i}$ - кількість балів за і-тим фактором $(i=1, \ldots, n) ; K_{i}-$ ваговий коєфіцієнт $i$-того фактору $(i=1, \ldots, n)$. 
Перелік вагових косфіціснтів

\begin{tabular}{|l|c|}
\hline \multicolumn{1}{|c|}{ Показник } & $\begin{array}{c}\text { Ваговий } \\
\text { коєфіцієнт }\end{array}$ \\
\hline порядок скликання та проведення Загальних зборів акціонерів & 0,10 \\
\hline порядок емісії акцій товариства & 0,08 \\
\hline робота Спостережної ради товариства & 0,10 \\
\hline організація роботи виконавчого органу товариства & 0,10 \\
\hline розкриття інформації та ії прозорість & 0,12 \\
\hline контроль за фінансово-господарською діяльністю товариства & 0,10 \\
\hline рентабельність капіталу & 0,02 \\
\hline рентабельність власного капіталу & 0,05 \\
\hline період окупності власного капіталу & 0,05 \\
\hline коєфіцієнт фінансової незалежності & 0,10 \\
\hline коєфіцієнт фінансової стабільності & 0,05 \\
\hline прибуток на одну акцію & 0,05 \\
\hline дивіденд на акцію & 0,05 \\
\hline дивідендний вихід & 0,03 \\
\hline Джерело: розробло авпоролсамостій.
\end{tabular}

Джерело: розроблено автором самостійно.

На основі сумарного балу оцінки рівня корпоративного управління акціонерні товариства ранжують за класами А, Б, В, Г та Д. Відповідні розрахунки рейтингу корпоративного управління Товариства здійснюються за допомогою розробленої нами прикладної програми на основі Excel 2000. Ранжування акціонерних товариств на класи здійснюється за допомогою табл. 17.

Таблиия 17

Критерії оцінки стану корпоративного управління акціонерного товариства

\begin{tabular}{|c|c|c|}
\hline Клас & Характеристика класу & $\begin{array}{c}\text { Сумарний } \\
\text { бал }\end{array}$ \\
\hline A & $\begin{array}{l}\text { Акціонерне товариство проводить ефективне корпоративне управління, } \\
\text { яке характеризується відкритістю інформації щодо основних напрямів } \\
\text { діяльності, взаємовідносин } 3 \text { акціонерами, Спостережною радою та } \\
\text { Ревізійною комісією. Аналіз коєфіцієнтів оцінки прибутковості та } \\
\text { ринкової активності Товариства свідчить про позитивні тенденції в } \\
\text { його діяльності. Товариство проводить послідовну дивідендну політику, } \\
\text { яка є відкритою для акціонерів }\end{array}$ & $\begin{array}{c}\text { Від } 4,2 \\
\text { до } 5,0\end{array}$ \\
\hline Б & $\begin{array}{l}\text { Акціонерне товариство проводить ефективне корпоративне управління, } \\
\text { яке характеризується відкритістю інформації щодо основних напрямів } \\
\text { діяльності, взаємовідносин з акціонерами, Спостережною радою та } \\
\text { Ревізійною комісією, проте є інформація про ймовірність неможливості } \\
\text { підтримки його на цьому рівні протягом тривалого часу. Товариства, } \\
\text { які віднесені до цього класу, потребують більшої уваги через потенційні } \\
\text { недоліки, що ставлять під загрозу ефективне корпоративне управління. } \\
\text { Аналіз коєфіцієнтів оцінки прибутковості та ринкової активності } \\
\text { Товариства може вказувати на негативні тенденції в його діяльності }\end{array}$ & $\begin{array}{c}\text { Від } 3,4 \\
\text { до } 4,2\end{array}$ \\
\hline
\end{tabular}


Продовження табл. 17

\begin{tabular}{|c|c|c|}
\hline B & $\begin{array}{l}\text { Акціонерне товариство проводить корпоративне управління, яке } \\
\text { характеризується недостатнім рівнем інформаційної відкритості } \\
\text { щодо основних напрямів діяльності, взаємовідносин } 3 \text { акціонерами, } \\
\text { Спостережною радою та Ревізійною комісією. Товариство проводить } \\
\text { відкриту підписку на випущені акції, що не мають високої ринкової } \\
\text { вартості та не надходять у вільний обіг на фондовому ринку. } \\
\text { Спостережна рада Товариства здійснює лише контроль за діяльністю } \\
\text { виконавчого органу й доповідає про це на Загальних зборах акціонерів. } \\
\text { Аналіз коєфіцієнтів оцінки прибутковості та ринкової активності } \\
\text { Товариства вказує на негативні тенденції в його діяльності. }\end{array}$ & $\begin{array}{c}\text { Від 2,6 } \\
\text { до } 3,4\end{array}$ \\
\hline$\Gamma$ & $\begin{array}{l}\text { Акціонерне товариство проводить корпоративне управління, яке } \\
\text { характеризується недостатнім рівнем інформаційної відкритості } \\
\text { щодо основних напрямів діяльності та взаємовідносин з акціонерами. } \\
\text { Акції товариства мають низьку ринкову вартість і не користуються } \\
\text { попитом на фондовому ринку. Спостережна рада Товариства здійснює } \\
\text { лише візуальний контроль за діяльністю виконавчого органу й } \\
\text { доповідає про це на Загальних зборах акціонерів, а для детальної } \\
\text { перевірки запрошуютья зовнішні аудиторську фірми. Аналіз діяльності } \\
\text { Товариства вказує на неприбутковість та низьку ринкову активність. }\end{array}$ & $\begin{array}{c}\text { Від } 1,8 \\
\text { до } 2,6\end{array}$ \\
\hline Д & $\begin{array}{l}\text { Акціонерне товариство проводить корпоративне управління, яке } \\
\text { характеризуєтья недостатнім рівнем професіоналізму та інформаційної } \\
\text { відкритості. Акції товариства мають низьку ринкову вартість і не } \\
\text { користуються попитом на фондовому ринку. Спостережна рада здійснює } \\
\text { контроль за діяльністю виконавчого органу на громадських засадах, } \\
\text { ї̈ члени не мають достатньої кваліфікації та досвіду роботи у цій сфері. } \\
\text { Аналіз діяльності Товариства вказує на неприбутковість і низьку ринкову } \\
\text { активність. Імовірність виконання зобов’язань Товариства перед } \\
\text { акціонерами є низькою. }\end{array}$ & Менше 1,8 \\
\hline
\end{tabular}

Джерело: розроблено автором самостійно.

Отримані результати, що характеризують стан корпоративного управління в акціонерному товаристві, автор пропонує використовувати при прогнозуванні стану економічної безпеки емісійної діяльності.

\section{Висновки:}

Отже, запропонований інструментарій сприятиме оцінюванню стану корпоративного управління за умов економічної невизначеності, що дозволить виокремити фактори, які впливають на діяльність акціонерних товариств, та удосконалити стратегію розвитку корпорацій.

\section{Jimepamypa:}

1932.

1. Berle A., Means G. The Modern Corporation and Private Property.

2. Свтушевський В. А. Корпоративне управління: підручник. Київ : Знання, 2006. 408 с.

3. Задихайло Д. В. Корпоративне управління : навч. посіб. для студ. вищ. навч. закл. Харків : Еспада, 2003. 688 с. 
4. Господарський кодекс України від 16.01.2003 p. №436-IV. Редакція від 16.08.2020, підстава - 815-IX. URL : https://zakon.rada.gov. ua/laws/show/436-15\#Text.

5. Про акціонерні товариства : Закон України №514-VI від 17.09.2008 p. Редакція від 16.08.2020, підстава - 738-IX. URL : https://zakon.rada.gov.ua/laws/show/514-17\#Text.

6. Момот Т. В. Вартісно-орієнтоване корпоративне управління: від теорії до практичного впровадження : монографія. Харків : ХНАМГ, 2006. $380 \mathrm{c}$.

7. Верба В. А. Становлення корпоративного управління як чинник попиту на консалтингові послуги в Україні. Механізм регулювання економіки. 2009. №1. С. 92-101.

8. Ліщинський М. П. Система корпоративного управління в умовах трансформаційного розвитку аграрного сектору економіки України. Науковий вісник Національного університету біоресурсів $i$ природокористування Украӥни. 2010. Вип. 154. Частина 2. URL : http://www.nbuv.gov.ua/portal/chem_biol/nvnau/2010_154_2/10lmp.pdf.

9. Корпоративне управління : підручник / Мостенська Т. Л., Новак В. О., Луцький М. Г., Симоненко Ю. Г. Київ : Каравелла; Піча Ю. В., 2008. $384 \mathrm{c}$.

10. Хабарова И. А. Корпоративное управление: вопросы интеграции, аффилированные лица, организационное проектирование, интеграционная динамика : учебное пособие. Москва : Издательский дом «Альпина», 2000.

11. Довгань Л. С., Пастухова В. В., Савчук Л. М. Управління корпораціями : монографія. Київ : ІВЦ Вид-во «Політехніка», 2004. 236 с.

12. Формування моделі корпоративного управління в трансформаційній економіці : навч. посіб. / Круш П. В., Кавтиш О. П., Гречко А. В., Чихачова Ю. С.; під заг. ред. к.е.н., проф. П. В. Круша. Київ : ЦУЛ, 2007. 264 с.

13. Мігус І. П. Ринок фінансових послуг: методичні рекомендації для складання рейтингів суб'єктів господарювання : навч. посібник. Київ : Європейський університет, 2005. 188 с.

14. Про схвалення Методичних рекомендацій Державної комісії 3 цінних паперів та фондового ринку щодо створення та розвитку незалежних інформаційних та рейтингових агентств, що спеціалізуються на наданні інформаційних послуг на фондовому ринку України : Рішення Державної комісії $з$ цінних паперів та фондового ринку №370 від 31.08.2004p. URL : http://search.ligazakon.ua/__doc2.nsf/link1/KML04477.html.

15. Про схвалення Концепції створення системи рейтингової оцінки регіонів, галузей національної економіки, суб'єктів господарювання : Розпорядження Кабінету Міністрів України №208-р від 1 квітня 2004 р. URL : https://zakon.rada.gov.ua/laws/show/208-2004-\%D1\%80\#Text. 
16. Рябота В. Корпоративний секретар : посібник. Київ : Міжнародна фінансова корпорація, 2005. 160 с.

17. Пособие по корпоративному управлению: в 6 т. Т. 1: Часть 1. Введение в корпоративное управление. Москва : Альпина Бизнес Букс, $2004.93 \mathrm{c}$.

18. Пособие по корпоративному управлению: в 6 т. Т. 2: Часть 2. Совет директоров и исполнительные органы общества. Москва : Альпина Бизнес Букс, 2004. 141 с.

19. Пособие по корпоративному управлению: в 6 т. Т. 3: Часть 3. Права акционеров. Москва : Альпина Бизнес Букс, 2004. 233 с.

20. Пособие по корпоративному управлению: в 6 т. Т. 4: Часть 4. Раскрытие информации и прозрачность. Москва : Альпина Бизнес Букс, 2004. $111 \mathrm{c}$.

21. Пособие по корпоративному управлению: в 6 т. Т. 5: Часть 5. Некоторые специальные вопросы. Москва : Альпина Бизнес Букс, 2004. 108 c.

22. Пособие по корпоративному управлению: в 6 т. Т. 6: Часть 6. Приложения. Типовые документы. Москва : Альпина Бизнес Букс, 2004. $365 \mathrm{c}$.

23. Балабаров С., Рябота В., Михайлюк О. Ефективна рада : посібник. Київ : Міжнародна фінансова корпорація, 2007. 112 с.

24. Про внесення змін до деяких законодавчих актів України щодо відповідальності за правопорушення на ринку цінних паперів України: Закон України №801-VI від 25 грудня 2008 р. Редакція від 19.11.2012, підстава - 4651-VI. URL : https://zakon.rada.gov.ua/laws/show/ 801-17\#Text.

25. Мартін Джон Д., Петті Вільям Дж. VBM - управління, що базується на вартості : Корпоративна відповідь революції акціонерів / пер. 3 англ.; за наук. ред. О. Б. Максимової, І. Ю. Шарапової. Дніпропетровськ : Баланс Бізнес Букс, 2006. 272 с. 


\section{ДОДАТОК А}

Таблиия A. 1

Сутність принципів корпоративного управління ОЕСР

\begin{tabular}{|c|c|}
\hline $\begin{array}{c}\text { Визначення } \\
\text { принцпу }\end{array}$ & Зміст принципу \\
\hline $\begin{array}{c}\text { Захист прав } \\
\text { акціонерів }\end{array}$ & $\begin{array}{l}\text { А) Основні права акціонерів: надійні методи реєстрації власності; } \\
\text { передача акцій; регулярне та своєчасне отримання інформації } \\
\text { про корпорацію; участь і голосування на Загальних зборах } \\
\text { акціонерів; участь у виборах Ради; отримання частки прибутку } \\
\text { корпорації. } \\
\text { Б) Акціонери мають право на участь у прийнятті рішень та } \\
\text { отриманні достатньої інформації стосовно питань, пов'язаних з } \\
\text { фундаментальними змінами в корпорації. } \\
\text { В) Акціонери повинні мати можливість ефективно брати участь } \\
\text { у Загальних зборах акціонерів та голосувати на зборах, а також } \\
\text { бути поінформованими про правила, включаючи порядок } \\
\text { голосування, що регламентують проведення Загальних зборів. } \\
\text { Г) Підлягають оприлюдненню (розкриттю) структра капіталу } \\
\text { та механізми, які дозволяють окремим акціонерам отримувати } \\
\text { контроль, що не зіставний з їхною часткою в акціонерній } \\
\text { власності. } \\
\text { Д) Ринки корпоративного контролю повинні мати можливість } \\
\text { функціонувати ефективно і прозоро. } \\
\text { Е) Акціонери, в тому числі інституційні інвестори, мають } \\
\text { враховувати, які витрати та вигоди несе використання ними } \\
\text { свого права голосу. }\end{array}$ \\
\hline $\begin{array}{c}\text { Рівне } \\
\text { ставлення до } \\
\text { всіх } \\
\text { акціонерів, } \\
\text { включаючи } \\
\text { іноземних та } \\
\text { мінорітарних }\end{array}$ & $\begin{array}{l}\text { А) Ставлення до всіх акціонерів, які є власниками акцій одного } \\
\text { виду, має бути однаковим. } \\
\text { Б) Необхідно заборонити будь-які операції у власних інтересах } \\
\text { та операції з використанням закритої інформації. } \\
\text { В) Члени Спостережної ради та Правління зобов'язані повідомити } \\
\text { про свою матеріальну зацікавленість в угодах або питаннях, що } \\
\text { стосуються корпорації. }\end{array}$ \\
\hline $\begin{array}{c}\text { Роль } \\
\text { зацікавлених } \\
\text { осіб в } \\
\text { управлінні } \\
\text { компанією }\end{array}$ & $\begin{array}{l}\text { А) Система корпоративного управління має забезпечувати } \\
\text { дотримання захищених законом прав зацікавлених осіб. } \\
\text { Б) Якщо їхні інтереси захищені законом, зацікавлені особи повинні } \\
\text { мати можливість використовувати ефективні методи захисту в } \\
\text { разі порушення їхіх прав. } \\
\text { В) Система корпоративного управління повинна дозволяти } \\
\text { участь зацікавлених осіб у заходах для підвищення ефективності } \\
\text { діяльності компанії. } \\
\text { Г) Якщо зацікавлені особи беруть участь у процесі корпоративного } \\
\text { управління, вони повинні мати доступ до необхідної інформації. }\end{array}$ \\
\hline
\end{tabular}


Продовження табл. А. 1

\begin{tabular}{|c|c|}
\hline $\begin{array}{c}\text { Розкриття } \\
\text { інформації та } \\
\text { прозорість }\end{array}$ & $\begin{array}{l}\text { А) Інформація, що підлягає розкриттю, повинна включати: } \\
\text { результати фінансової та операційної (господарської) діяльності } \\
\text { компанії; завдання компанії; володіння значними пакетами } \\
\text { акцій і права голосу; список членів Ради та Правління, а також } \\
\text { розмір винагороди, яку кожен з них отримує; значущі фактори } \\
\text { ризику, що можна спрогнозувати; важливі питання, які пов'язані } \\
3 \text { працівниками та іншими зацікавленими особами; структура й } \\
\text { політика управління компанією. } \\
\text { Б) Інформація повинна готуватися, перевірятися та розкриватися } \\
\text { відповідно до високих стандартів якості розкриття фінансової й } \\
\text { нефінансової інформації та аудиту. } \\
\text { В) } 3 \text { метою забезпечення належної підготовки та надання } \\
\text { фінансової звітності слід щороку проводити аудиторські перевірки } \\
\text { з використанням незалежного аудитора, який дає зовнішню й } \\
\text { об'єктивну оцінку цієї звітності. } \\
\text { Г) Канали розповсюдження інформації повинні передбачати } \\
\text { рівноправний, своєчасний та не пов’язаний із надмірними витратами } \\
\text { доступ користувачів до необхідної інформації. }\end{array}$ \\
\hline $\begin{array}{c}\text { Обов'язки } \\
\text { Ради }\end{array}$ & $\begin{array}{l}\text { А) Члени Ради повинні діяти на основі всієї необхідної } \\
\text { інформації, сумлінно, з належною обачністю та обережністю, в } \\
\text { найкращих інтересах компанії і акціонерів. } \\
\text { Б) Якщо рішення Ради можуть по-різному впливати на різні } \\
\text { групи акціонерів, вона має однаково справедливо ставитися до всіх } \\
\text { акціонерів. } \\
\text { В) Рада повинна забезпечити дотримання відповідного законодавства } \\
\text { та враховувати інтереси зацікавлених осіб. } \\
\text { Г) Рада повинна виконувати певні ключові функції. } \\
\text { Д) Рада повинна мати можливість виносити об'єктивне, незалежне, } \\
\text { зокрема від Правління, судження у справах акціонерів. } \\
\text { Е) Щоб мати можливість виконувати свої обов'язки, члени Ради } \\
\text { повинні мати доступ до інформації, яка є точною, своєчасною і } \\
\text { стосується справи. }\end{array}$ \\
\hline
\end{tabular}




\section{ДОДАТОК Б}

AHKETA

для визначення вагових коєфіціснтів якісних та кількісних показників оцінки корпоративного управління акціонерного товариства

\begin{tabular}{|l|l|l|l|l|l|}
\hline \multicolumn{1}{|c|}{ Показники } & $\mathbf{5}$ & $\mathbf{4}$ & $\mathbf{3}$ & $\mathbf{2}$ & $\mathbf{1}$ \\
\hline $\begin{array}{l}\text { Порядок скликання та проведення } \\
\text { Загальних зборів акціонерів }\end{array}$ & & & & & \\
\hline Порядок емісії акцій товариства & & & & & \\
\hline Робота Спостережної ради товариства & & & & & \\
\hline $\begin{array}{l}\text { Організація роботи виконавчого } \\
\text { органу товариства }\end{array}$ & & & & & \\
\hline Розкриття інформації та ііі прозорість & & & & & \\
\hline $\begin{array}{l}\text { Контроль за фінансово-господарською } \\
\text { діяльністю товариства }\end{array}$ & & & & & \\
\hline Рентабельність капіталу & & & & & \\
\hline Рентабельність власного капіталу & & & & & \\
\hline Період окупності власного капіталу & & & & & \\
\hline $\begin{array}{l}\text { Коєфіцієнт фінансової стійкості } \\
\text { (незалежності) }\end{array}$ & & & & & \\
\hline $\begin{array}{l}\text { Коєфіцієнт фінансової стабільності } \\
\text { коєфіцієнт фінансування) }\end{array}$ & & & & & \\
\hline Прибуток на одну акцію & & & & & \\
\hline Дивіденд на акцію & & & & & \\
\hline Дивідендний вихід & & & & & \\
\hline
\end{tabular}




\section{ДОДАТОК В}

\section{AHKETA \\ для проведення якісної оцінки корпоративного управління при складанні рейтингу корпоративного управління}

1. Найменування юридичної особи

2. Ідентифікаційний код (СДРПОУ)

3. Місцезнаходження

4. Юридична адреса

5. E-mail або Інтернет-сайт

6. Дата проведення та орган державної ресстрації

7. Види діяльності за КВЕД

8. Система оподаткування (підкреслити) - загальна, фіксований сільськогосподарський податок, єдиний податок $(3 \%, 5 \%)$.

9. Розмір статутного капіталу

10. Номінальна вартість акцій

11. Кількість випущених акцій

12. Чисельність акціонерів та їх частка

- юридичні особи -

- фізичні особи -

13. Перелік акціонерів, частка яких у статутному капіталі перевищус $10 \%$

14. Ліцензії, отримані на здійснення певних видів діяльності:

15. Керівник (директор, Голова Правління) підприсмства:

П.I.Б.

Дата народження _ـ Код

Освіта

Досвід роботи за фахом

Стаж роботи на займаній посаді

16. Головний бухгалтер:

П.I.Б.

Дата народження

Код

Освіта

Досвід роботи за фахом

Стаж роботи на займаній посаді

17. Заступник керівника (директора, Голови Правління) з фінансових питань:

П.І.Б.

Дата народження

Код

Освіта

Досвід роботи за фахом

Стаж роботи на займаній посаді 
18. Голова Спостережної ради:

П.І.Б.

Дата народження _ К Код

Освіта

Досвід роботи за фахом

Стаж роботи на займаній посаді

19. Голова ревізійної комісії:

П.І.Б.

Дата народження _ـ Код

Освіта

Досвід роботи за фахом

Стаж роботи на займаній посаді

20. Наявність заресстрованої торговельної марки (так, ні )

21. Кількість років діяльності підприємства

22. Наявність внутрішнього контролю на підприємстві та його форма

23. Періодичність проведення обов'язкових аудиторських перевірок

24. Періодичність проведення тематичних аудиторських перевірок

25. Скільки років співпрацюєте з аудиторською фірмою. Якщо вона часто змінюється, то чому?

26. Результати проведення перевірок державних органів - адміністративні, фінансові, кримінальні санкції (необхідне підкреслити та розшифрувати).

27. Як часто в акціонерному товаристві скликаються Загальні збори акціонерів?

1) щороку, один раз на рік;

2) щороку, кожні дев'ять місяців;

3) щороку, кожні пів року.

28. Як часто в акціонерному товаристві скликаються позачергові Загальні збори акціонерів?

1) щороку, один раз на рік;

2) щороку, кожні дев'ять місяців;

3) щороку, кожні пів року;

4) жодного разу не скликалися.

29. Де проходять Загальні збори акціонерів?

1) на території самого акціонерного товариства;

2) за межами акціонерного товариства, але у місті, де воно зареєстроване;

3) в іншому місті.

30. Хто здійснює організацію та проведення Загальних зборів акціонерів?

1) виконавчий орган акціонерного товариства (Правління);

2) Спостережна рада акціонерного товариства;

3) незалежний реєстратор;

4) представники Державної комісії з цінних паперів та фондового ринку;

5) мандатна комісія, призначена Правлінням;

6) інше. 
31. Хто здійснює контроль за ресстрацією акціонерів та їх представників, які беруть участь у Загальних зборах?

1) виконавчий орган акціонерного товариства (Правління);

2) Спостережна рада акціонерного товариства;

3) незалежний реєстратор;

4) представники акціонерів;

5) представники Державної комісії з цінних паперів та фондового ринку;

6) інші особи;

7) контроль не здійснювався.

32. Яким чином проводиться голосування під час Загальних зборів акціонерів?

1) $з$ допомогою карток;

2) шляхом підняття рук;

3) $з$ допомогою мандатів;

4) 3 допомогою бюлетенів, затверджених Спостережною радою;

5) з допомогою бюлетенів, затверджених Загальними зборами акціонерів.

33. Хто веде протокол засідання Загальних зборів акціонерів?

1) секретар Загальних зборів акціонерного товариства;

2) представник Спостережної ради;

3) корпоративний секретар;

4) працівник відділу роботи з акціонерами.

34. Хто здійснюс підрахунок голосів під час проведення Загальних зборів акціонерів?

1) лічильна комісія, обрана Загальними зборами акціонерів;

2) лічильна комісія, затверджена Спостережною радою;

3) лічильна комісія, затверджена Правлінням акціонерного товариства.

35. Хто відповідає за зберігання протоколів Загальних зборів акціонерів?

1) корпоративний секретар;

2) секретар Загальних зборів акціонерного товариства;

3) представник Спостережної ради;

4) представник виконавчого органу акціонерного товариства;

5) відділ роботи з акціонерами.

36. Скільки осіб входить до складу Спостережної ради акціонерного товариства?

1) менше 4 осіб;

2) 4 особи;

3) 5 осіб;

4) більше 5 осіб.

37. Хто входить до складу Спостережної ради?

1) працівники акціонерного товариства;

2) акціонери;

3) незалежні експерти.

38. Яка кількість проведених засідань Спостережної ради на рік?

1) менше 3 засідань;

2) 3-4 засідання;

3) 4-6 засідань;

4) більше 6 засідань.

39. Скільки осіб входить до складу Ревізійної комісії акціонерного товариства?

1) менше 4 осіб;

2) 4 особи;

3) 5 осіб;

4) більше 5 осіб.

40. Хто входить до складу ревізійної комісії?

1) працівники акціонерного товариства;

2) акціонери;

3) незалежні експерти. 
41. Яка кількість проведених засідань Ревізійної комісії на рік?

1) менше 3 засідань;

2) 3 - 4 засідання;

3) 4 - 6 засідань;

4) більше 6 засідань.

42. Хто розробляє стратегію діяльності акціонерного товариства?

1) загальні збори акціонерів;

2) Спостережна рада;

3) Правління.

43. До чиєї компетенції належать питання обрання та відкликання членів виконавчого органу (Правління)?

1) Спостережній раді;

2) Загальним зборам акціонерів.

44. Чи передбачені Статутом обмеження для представників виконавчого органу щодо укладання угод від імені акціонерного товариства, за яких рішення про укладання таких угод приймається виключно Загальними зборами акціонерів?

1) не передбачені;

2) передбачені, залежно від суми угоди у відсотках від розміру статутного капіталу акціонерного товариства;

3) передбачені, залежно від суми угоди у відсотках від розміру балансової вартості активів акціонерного товариства;

4) передбачені інші обмеження.

45. Чи мають посадові особи виконавчого органу акціонерного товариства особисту зацікавленість у здійсненні товариством своєї діяльності (конфлікт інтересів)?

1) найбільшим акціонером $є$ голова Правління;

2) найбільшим акціонером є голова Спостережної ради;

3) найбільшими акціонерами є члени Правління;

4) найбільшими акціонерами є незацікавлені особи.

46. Яким чином урегульовані відносини між товариством та членами Спостережної ради?

1) шляхом укладання цивільно-правових договорів, у яких передбачена оплата їх праці та інші взаємовідносини;

2) на громадських засадах;

3) іншим способом

47. Якими документами передбачені основні права й обов'язки Голови та членів Правління акціонерного товариства?

1) Цивільним кодексом України;

2) Статутом акціонерного товариства;

3) Установчим договором акціонерного товариства;

4) Положенням про роботу Правління акціонерного товариства;

5) іншими документами.

48. Якими документами передбачені основні права й обов'язки Голови та членів Спостережної ради акціонерного товариства?

1) Цивільним кодексом України;

2) Статутом акціонерного товариства;

3) Установчим договором акціонерного товариства;

4) Положенням про роботу Спостережної ради акціонерного товариства;

5) іншими документами.

49. Яким чином здійснюється розповсюдження інформації про діяльність акціонерного товариства?

1) Товариство регулярно здає річний звіт встановленої форми до ДКЦПФР;

2) Товариство регулярно публікує річний звіт встановленої форми в одному з офіційних видань ДКЦПФР;

3) Товариство оприлюднює свою річну звітність на Інтернет-сайті; 
4) Товариство розповсюджує річний звіт разом з аудиторським висновком серед акціонерів, клієнтів, партнерів та інвесторів;

5) про всі зміни у фінансово-господарській діяльності, які можуть вплинути на вартість цінних паперів або доходу по них, Товариство повідомляє не пізніше 2 днів 3 дати виникнення;

6) Товариство регулярно звертається до рейтингових агентств для оцінки його фінансового стану та складання кредитного рейтингу.

50. Яким чином повідомляються акціонери про проведення Загальних зборів та про їх порядок денний?

1) оголошення про скликання Загальних зборів акціонерів друкується у спеціалізованій та місцевій пресі не пізніше як за 45 днів до їх проведення;

2) кожному з акціонерів надсилається оголошення про проведення Загальних зборів акціонерного товариства та їх порядок денний;

3) акціонерам надається можливість ознайомитися 3 документами, пов'язаними 3 порядком денним;

4) акціонери мають право вносити пропозиції щодо доповнення порядку денного окремими питаннями не пізніше 30 днів до скликання Загальних зборів;

5) акціонери мають можливість одержати повну та достовірну інформацію про фінансово-господарський стан Товариства і результати його діяльності.

51. Які акції випускає акціонерне товариство?

1) Товариство здійснювало емісію звичайних іменних акцій у документарній формі;

2) Товариство здійснювало емісії звичайних іменних акцій у бездокументарній формі;

3) Товариство здійснювало емісію звичайних акцій на пред'явника у документарній формі;

4) Товариство здійснювало емісію звичайних акцій на пред’явника у бездокументарній формі;

5) Товариство здійснювало емісію привілейованих іменних акцій у документарній формі;

6) Товариство здійснювало емісії привілейованих іменних акцій у бездокументарній формі;

7) Товариство здійснювало емісію привілейованих акцій на пред’явника у документарній формі;

8) Товариство здійснювало емісію привілейованих акцій на пред’явника у бездокументарній формі.

52. Хто веде реєстр власників акцій Товариства?

1) реєстр ведеться на підприємстві;

2) реєстр ведеться незалежним реєстратором;

3) реєстр ведеться у депозитарії.

53. Як часто здійснюсться випуск акцій Товариством?

1) Товариство здійснювало емісію акцій лише при створенні;

2) Товариство здійснювало додаткову емісію акцій 1 раз;

3) Товариство здійснює додаткову емісію акцій більше 1 разу.

54. Яким чином акціонерне товариство поповнюс свої оборотні активи?

1) за рахунок прибутку;

2) за рахунок невиплачених дивідендів;

3) за рахунок банківських кредитів;

4) за рахунок додаткових емісій акцій;

5) за рахунок випуску облігацій;

6) за рахунок інвестицій інших підприємств;

7) іншим способом. 